\title{
Questions and answers in Evidence-based Dentistry Volume 12
}

\section{Derek Richards}

\section{Editor, Evidence-based Dentistry}

As in previous years we are highlighting the guidelines, questions and answers addressed by summaries in Evidence-based Dentistry. ${ }^{1-9}$ Evidence levels ${ }^{10}$ are only given for those papers achieving level $3 \mathrm{~A}$ and above.

Evidence-Based Dentistry (2011) 12, 123-126. doi:10.1038/sj.ebd.6400832

\section{Dental Evidence-based Topics (DEBT)}

\begin{tabular}{l|l|l|l|} 
Topic Area & Question & Answer & Page \\
\hline $\begin{array}{l}\text { Restorative } \\
\text { dentistry }\end{array}$ & $\begin{array}{l}\text { What is the best way to restore the worn } \\
\text { dentition? }\end{array}$ & $\begin{array}{l}\text { At present, there is only low level evidence from experts and } \\
\text { observational studies, personal clinical experience and patient } \\
\text { values to guide us in regard of which restorative option is } \\
\text { preferable in terms of longevity, preservation of vitality or } \\
\text { minimisation of opposing tooth wear. }\end{array}$ & $55-56$ \\
\hline
\end{tabular}

\section{Summaries}

\begin{tabular}{|c|c|c|c|c|}
\hline $\begin{array}{l}\text { Topic } \\
\text { area }\end{array}$ & Question & Answer & $\begin{array}{l}\text { Evidence } \\
\text { level }\end{array}$ & Page \\
\hline \multicolumn{5}{|l|}{ Caries } \\
\hline & $\begin{array}{l}\text { When undertaking stepwise excavation } \\
\text { of deep caries in permanent teeth what } \\
\text { methods and materials are most effective? }\end{array}$ & $\begin{array}{l}\text { More research is still needed to confirm that stepwise excavation } \\
\text { as opposed to other treatment modalities may be the treatment } \\
\text { of choice for the best preservation of the pulp in relation to the } \\
\text { treatment dilemma of the deep caries lesion. }\end{array}$ & $1 \mathrm{~b}$ & 68 \\
\hline & $\begin{array}{l}\text { In patients at risk of root caries, is } \\
\text { individualised oral hygiene instruction (OHI) } \\
\text { every three months, OHI and applications of } \\
\text { chlorhexidine varnish every three months, } \\
\text { OHI and applications of sodium fluoride } \\
\text { varnish every three months, or OHI and } \\
\text { annual applications of silver diamine fluoride } \\
\text { (SDF) solution most effective in preventing } \\
\text { root caries? }\end{array}$ & $\begin{array}{l}\text { This trial describes the addition of three test materials, in addition } \\
\text { to improvement in oral hygiene as being effective to prevent the } \\
\text { development of root caries in institutionalised elders in this specific } \\
\text { population - it may be wise to wait for a systematic review of this } \\
\text { topic to assess the reproducibility and generalisability of this result } \\
\text { especially with reference to other population groups and settings. }\end{array}$ & $1 \mathrm{~b}$ & $70-71$ \\
\hline & $\begin{array}{l}\text { Is a one yearly or two yearly school } \\
\text { programme using xylitol or erythritol } \\
\text { lozenges, as an adjunct to a comprehensive } \\
\text { oral health improvement programme } \\
\text { effective at reducing dental caries in } \\
\text { school children? }\end{array}$ & $\begin{array}{l}\text { The use of xylitol-maltitol or erythritol-maltitol lozenges within a } \\
\text { cohort of low caries children either over nine months or } 21 \text { months } \\
\text { were not effective in reducing dental caries in primary school } \\
\text { children. }\end{array}$ & $1 \mathrm{~b}$ & $102-103$ \\
\hline & $\begin{array}{l}\text { Is chlorhexidine varnish ( } \mathrm{CHX}-\mathrm{V} \text { ) effective for } \\
\text { the treatment of root caries? }\end{array}$ & $\begin{array}{l}\text { There is currently only weak evidence of a positive effect of } \mathrm{CHX}-\mathrm{V} \\
\text { on root caries and further high quality studies are necessary to } \\
\text { confirm effectiveness. }\end{array}$ & $2 a$ & $39-40$ \\
\hline & $\begin{array}{l}\text { Does fluoride varnish decrease the incidence } \\
\text { of caries in preschool children? }\end{array}$ & $\begin{array}{l}\text { The review was unable to show conclusive evidence of the benefit } \\
\text { of fluoride varnish for pre-school children and recommends further } \\
\text { robust randomised controlled trials be conducted of sufficient size } \\
\text { for this specific age group to provide high quality evidence. }\end{array}$ & $2 a$ & $41-42$ \\
\hline & $\begin{array}{l}\text { Is use of fluoridated salt an effective method } \\
\text { of reducing caries in children's permanent } \\
\text { teeth? }\end{array}$ & $\begin{array}{l}\text { There are insufficient studies with good quality evidence examining } \\
\text { the effects of salt fluoridation in preventing } \\
\text { dental caries. The included studies, however, suggested that } \\
\text { fluoridated salt was beneficial to children, especially their } \\
\text { permanent dentition. }\end{array}$ & $\mathrm{N} / \mathrm{a}$ & $17-18$ \\
\hline \multicolumn{5}{|c|}{ Caries \& Periodontal disease } \\
\hline & How do cancer treatments affect oral health? & $\begin{array}{l}\text { The incidence of oral complications in cancer patients can be } \\
\text { reduced significantly when an aggressive approach to oral care is } \\
\text { initiated prior to treatment. }\end{array}$ & $\mathrm{N} / \mathrm{a}$ & $15-16$ \\
\hline
\end{tabular}




\begin{tabular}{|c|c|c|c|}
\hline \multicolumn{4}{|l|}{ Evidence-based practice } \\
\hline $\begin{array}{l}\text { Do journal clubs support evidence-based } \\
\text { decision making? }\end{array}$ & $\begin{array}{l}\text { The effectiveness of JCs in supporting evidence-based decision } \\
\text { making is not clear. Better reporting of the intervention and a mixed } \\
\text { methods approach to evaluating active ingredients are needed in } \\
\text { order to understand how JCs may support evidence-based practice. }\end{array}$ & $\mathrm{N} / \mathrm{a}$ & $92-93$ \\
\hline $\begin{array}{l}\text { In the traditional health education curriculum } \\
\text { how effective is problem-based learning? }\end{array}$ & $\begin{array}{l}\text { Some evidence exists that single PBL intervention in a traditional } \\
\text { curriculum is an effective learning tool, though test results appear } \\
\text { not to be affected. }\end{array}$ & $\mathrm{N} / \mathrm{a}$ & $115-116$ \\
\hline
\end{tabular}

\section{Oral Cancer}

Is socio-economic status a risk factor for upper aerodigestive tract (UADT) cancers?

Is there a relationship between coffee and tea intake and head and neck cancers?
Socioeconomic effects on the risk of UADT cancer are not fully explained by the traditional behavioural factors of smoking, alcoho consumption and diet. Furthermore, the study showed that the association between the lowest levels of education and UADT cancer risk remained significant, while controlling for behavioural factors, and was consistent across UADT cancer subsites.

This pooled analysis of case-control studies supports the hypothesis of an inverse association between caffeinated coffee drinking and risk of cancer of the oral cavity and pharynx.

\section{Oral Medicine}

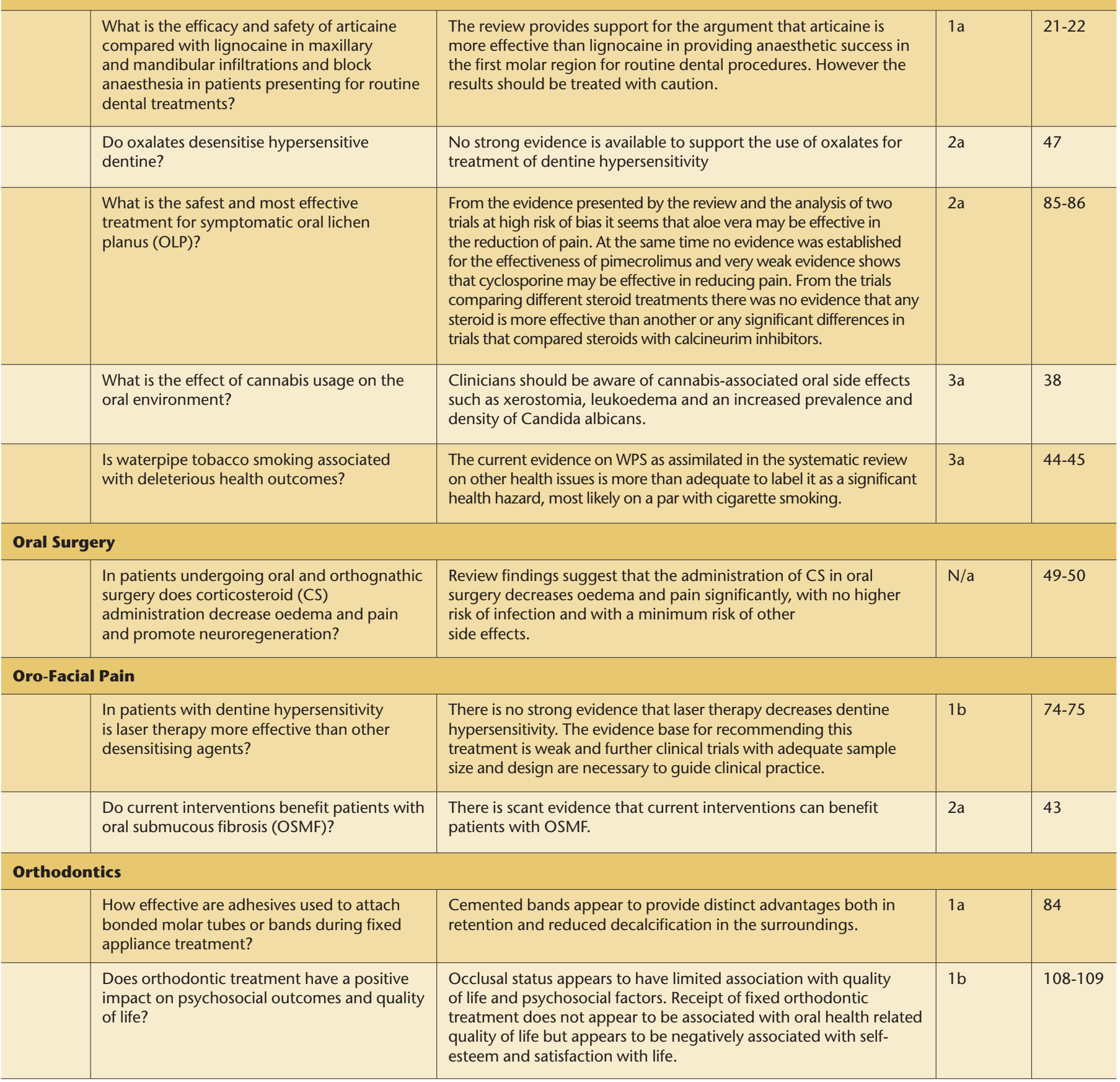




\begin{tabular}{|c|c|c|c|}
\hline $\begin{array}{l}\text { Is fluoride varnish effective in reverting white } \\
\text { spot lesions (WSLs) after fixed orthodontic } \\
\text { treatment? }\end{array}$ & $\begin{array}{l}\text { Topical fluoride varnish application appears to be a good method } \\
\text { to treat WSLs and should be advocated as a routine measure after } \\
\text { orthodontic treatment. }\end{array}$ & $1 b$ & 104-105 \\
\hline $\begin{array}{l}\text { Does interceptive treatment in the mixed } \\
\text { dentition prevent the impaction of the palatally } \\
\text { displaced maxillary permanent canine (PDC)? }\end{array}$ & $\begin{array}{l}\text { The scientific evidence was too weak to evaluate the effect of } \\
\text { interceptive treatment on PDCs or which treatment modalities are } \\
\text { most effective. }\end{array}$ & $2 b$ & $106-106$ \\
\hline $\begin{array}{l}\text { What are the success rates for mini-screws use } \\
\text { in orthodontics? }\end{array}$ & $\begin{array}{l}\text { Mini-screws can be used successfully to reinforce anchorage in } \\
\text { orthodontic treatment with current data suggesting a failure rate of } \\
\text { less than one in five. }\end{array}$ & $\mathrm{N} / \mathrm{a}$ & 19 \\
\hline $\begin{array}{l}\text { Do changes in incisor inclination due to } \\
\text { orthodontic treatment led to gingival } \\
\text { recession? }\end{array}$ & $\begin{array}{l}\text { An association was found between incisor inclination and gingival } \\
\text { recession, however there are very few clinical studies. All the studies } \\
\text { included in this review are retrospective and the biases associated } \\
\text { with this type of studies cannot be dismissed. }\end{array}$ & $\mathrm{N} / \mathrm{a}$ & 20 \\
\hline $\begin{array}{l}\text { What is the efficacy of cone beam computed } \\
\text { tomography (CBCT) in the diagnosis of } \\
\text { impacted teeth and associated features? }\end{array}$ & $\begin{array}{l}\text { This review reveals a need for studies that meet methodological } \\
\text { standards for diagnostic efficacy of CBCT in the diagnosis of } \\
\text { impacted teeth. }\end{array}$ & $\mathrm{N} / \mathrm{a}$ & 37 \\
\hline \multicolumn{4}{|l|}{ Periodontal Disease } \\
\hline $\begin{array}{l}\text { Does photodynamic therapy (PDT) improve } \\
\text { periodontal outcomes compared to scaling and } \\
\text { root planing (SRP) or no treatment? }\end{array}$ & $\begin{array}{l}\text { There is insufficient evidence that photodynamic therapy as an } \\
\text { independent treatment or as an adjunct to scaling and root planing } \\
\text { is superior to SRP alone. }\end{array}$ & $1 \mathrm{a}$ & 46 \\
\hline Does hospitalisation impact on oral health? & $\begin{array}{l}\text { Hospitalisation is associated with a deterioration in oral health, } \\
\text { particularly in intubated patients. }\end{array}$ & $1 \mathrm{a}$ & 48 \\
\hline $\begin{array}{l}\text { In adult patients is } 0.12 \% \text { chlorhexidine } \\
\text { mouthrinse }(\mathrm{CHX}) \text { as effective as } 0.2 \% \\
\mathrm{CHX} \text { in reducing plaque accumulation and } \\
\text { improving periodontal parameters? }\end{array}$ & $\begin{array}{l}\text { The evidence comparing different formulations of chlorhexidine } \\
\text { mouthrinse is weak; the results of this systematic review add strength } \\
\text { to those of earlier reviews of chlorhexidine as a valuable means of } \\
\text { chemical plaque control. For now, it appears that the higher strength } \\
\text { and the longer rinsing time may not make as much of a difference as } \\
\text { not using an antimicrobial mouthrinse to reduce plaque. }\end{array}$ & $1 \mathrm{a}$ & $8-9$ \\
\hline $\begin{array}{l}\text { Does photodynamic therapy (PDT) improve } \\
\text { outcomes in the treatment of periodontitis? }\end{array}$ & $\begin{array}{l}\text { The review suggests there may be a minor improvement in clinical } \\
\text { attachment loss at } 12 \text { weeks. It is unclear whether this is a clinically } \\
\text { meaningful improvement. }\end{array}$ & $1 \mathrm{a}$ & $78-79$ \\
\hline $\begin{array}{l}\text { Does the treatment of periodontitis and } \\
\text { gingivitis during pregnancy reduce the } \\
\text { number of preterm births? }\end{array}$ & $\begin{array}{l}\text { Scaling and root debridement in pregnant women with } \\
\text { periodontitis or gingivitis does not result in fewer preterm births. }\end{array}$ & $1 \mathrm{a}$ & 112 \\
\hline $\begin{array}{l}\text { Compared to manual toothbrushes are there } \\
\text { any adverse effects associated with the use of } \\
\text { oscillating-rotating powered brushes? }\end{array}$ & $\begin{array}{l}\text { This systematic review found no evidence that such toothbrushes } \\
\text { harmed the oral hard or soft tissues. }\end{array}$ & $1 \mathrm{~b}$ & 69 \\
\hline Does smoking cause tooth loss? & $\begin{array}{l}\text { Based on the consistent evidence a causal association between } \\
\text { smoking and tooth loss is highly likely. Further studies using a } \\
\text { cohort design and different populations are necessary to confirm } \\
\text { this association. }\end{array}$ & $2 a$ & 77 \\
\hline $\begin{array}{l}\text { In patients with chronic periodontitis is } \\
\text { treatment with erbium-doped:yttrium } \\
\text { aluminium garnet (Er:YAG) laser as effective as } \\
\text { scaling and root planing (SRP)? }\end{array}$ & $\begin{array}{l}\text { There is no apparent difference in clinical efficacy between SRP } \\
\text { and Er:YAG laser therapy. There is significant risk of bias in the } \\
\text { reported trials. Larger scale, masked randomised controlled trials } \\
\text { are needed. }\end{array}$ & $2 a$ & $80-81$ \\
\hline $\begin{array}{l}\text { Is alcohol consumption or dependence } \\
\text { associated with periodontitis? }\end{array}$ & $\begin{array}{l}\text { There is evidence to suggest alcohol consumption is a risk indicator } \\
\text { for periodontitis. }\end{array}$ & $\mathrm{N} / \mathrm{a}$ & 76 \\
\hline $\begin{array}{l}\text { Can a decision tree assist in deciding whether } \\
\text { to extract a periodontally involved tooth? }\end{array}$ & $\begin{array}{l}\text { This analysis does not offer a valid decision analysis to guide } \\
\text { clinicians or policy makers on the management of a periodontally } \\
\text { compromised tooth. }\end{array}$ & $\mathrm{N} / \mathrm{a}$ & $110-111$ \\
\hline \multicolumn{4}{|l|}{ Restorative Dentistry } \\
\hline $\begin{array}{l}\text { Do removable dental prostheses have an } \\
\text { impact on tooth loss? }\end{array}$ & $\begin{array}{l}\text { The difference in tooth loss at three years between patients treated } \\
\text { with RDP and those not treated with RDP was not significant. } \\
\text { However the prosthetic care described may make it impossible to } \\
\text { apply their findings to the wider population. }\end{array}$ & $1 \mathrm{~b}$ & 14 \\
\hline $\begin{array}{l}\text { Are scientific articles which are exclusively or } \\
\text { partially funded by implants companies more } \\
\text { likely to report lower annual implant failure } \\
\text { rates compared to articles with non-industry } \\
\text { associated sponsorship? }\end{array}$ & $\begin{array}{l}\text { There is now evidence to suggest that dental industry sponsored } \\
\text { research is more likely to report more favourable outcomes than } \\
\text { research from non-industry sponsored research. }\end{array}$ & $2 \mathrm{~b}$ & $5-6$ \\
\hline
\end{tabular}




\begin{tabular}{|c|c|c|c|c|}
\hline & $\begin{array}{l}\text { What factors affect tooth survival following } \\
\text { non-surgical root canal treatment }(\mathrm{RCTx}) \text { ? }\end{array}$ & $\begin{array}{l}\text { The proportion of teeth surviving } 2-10 \text { years following RCTx } \\
\text { ranged between } 86 \% \text { and } 93 \% \text {. Four factors: (i) a crown } \\
\text { restoration after RCTx; (ii) tooth having both mesial and distal } \\
\text { proximal contacts; (iii) tooth not functioning as an abutment for } \\
\text { removable or fixed prosthesis; and (iv) tooth type or specifically } \\
\text { non-molar teeth were identified as significant prognostic factors. }\end{array}$ & $2 b$ & $10-11$ \\
\hline & $\begin{array}{l}\text { What factors influence the prognosis of apical } \\
\text { surgery with root-end filling? }\end{array}$ & $\begin{array}{l}\text { This meta-analysis summarised evidence of the prognostic } \\
\text { factors for healing after apical surgery with root-end filling. While } \\
\text { the paper pools the results of each of the prognostic factors, } \\
\text { several methodological issues preclude one from making strong } \\
\text { conclusions regarding the importance of individual factors. }\end{array}$ & $2 b$ & $12-13$ \\
\hline & $\begin{array}{l}\text { What is the prognosis of short implants when } \\
\text { placed in the partially edentulous patient? }\end{array}$ & $\begin{array}{l}\text { Short implants seem to be a viable alternative to longer implants } \\
\text { as well as to augmentation techniques over a follow-up of about } \\
\text { two years. Beyond the first years following implant placement } \\
\text { the current scientific data are insufficient for providing clinical } \\
\text { guidance. }\end{array}$ & $2 b$ & $99-101$ \\
\hline & $\begin{array}{l}\text { Do studies on treatment for } \\
\text { peri-implantitis use true endpoints for } \\
\text { outcome? }\end{array}$ & $\begin{array}{l}\text { Traditionally used clinical surrogate endpoints for peri-implantitis } \\
\text { treatments are possibly not indicating the true endpoint (implant } \\
\text { removal), thus further validation is necessary. }\end{array}$ & $\mathrm{N} / \mathrm{a}$ & 7 \\
\hline & $\begin{array}{l}\text { In adult patients who have had nonsurgical } \\
\text { root canal treatment, does the presence of } \\
\text { an adequate root filling and an inadequate } \\
\text { coronal restoration compared with the } \\
\text { presence of an inadequate root filling and an } \\
\text { adequate coronal restoration result in a worse } \\
\text { clinical outcome? }\end{array}$ & $\begin{array}{l}\text { The odds for healing of apical periodontitis increase with both } \\
\text { adequate root canal treatment and adequate restorative treatment. } \\
\text { Although poorer clinical outcomes may be expected with adequate } \\
\text { root filling in adequate coronal restoration and inadequate } \\
\text { root filling-adequate coronal restoration, there is no significant } \\
\text { difference in the odds of healing between these two combinations. }\end{array}$ & $\mathrm{N} / \mathrm{a}$ & $72-73$ \\
\hline & $\begin{array}{l}\text { Can dental implants osseointegrate and } \\
\text { remain functionally stable in patients having } \\
\text { undergone oral cancer treatment? }\end{array}$ & $\begin{array}{l}\text { Dental implants can osseointegrate and remain functionally stable } \\
\text { in patients having undergone oral cancer therapy. }\end{array}$ & $\mathrm{N} / \mathrm{a}$ & $82-83$ \\
\hline \multicolumn{5}{|c|}{ Service delivery \& organisation of care } \\
\hline & $\begin{array}{l}\text { Within general and oral healthcare is } \\
\text { the transfer of care from secondary to } \\
\text { primary settings effective; and what is the } \\
\text { effectiveness of increased use of skill-mix? }\end{array}$ & $\begin{array}{l}\text { There was limited evidence of the cost-effectiveness and health } \\
\text { outcomes associated with changes in setting and skill-mix. } \\
\text { However, there was evidence of improved access, patient and } \\
\text { professional satisfaction. }\end{array}$ & $\mathrm{N} / \mathrm{a}$ & 51 \\
\hline \multicolumn{5}{|c|}{ Temporomandibular disorders } \\
\hline & $\begin{array}{l}\text { Is acupuncture or acupuncture-like } \\
\text { therapy effective for the treatment of } \\
\text { temporomandibular joint disorders(TMD)? }\end{array}$ & $\begin{array}{l}\text { This review suggests that acupuncture may remain a therapeutic } \\
\text { opportunity in patients suffering from temporomandibular pain. }\end{array}$ & $1 b$ & 89 \\
\hline & $\begin{array}{l}\text { Is arthroscopy effective for the management } \\
\text { of signs and symptoms in patients with } \\
\text { temporomandibular joint disorders (TMD)? }\end{array}$ & $\begin{array}{l}\text { Both arthroscopy and nonsurgical treatments reduced pain after } \\
\text { six months. When compared with arthroscopy, open surgery was } \\
\text { more effective at reducing pain after } 12 \text { months. Nevertheless, } \\
\text { there were no differences in mandibular functionality or in other } \\
\text { outcomes in clinical evaluations. Arthroscopy led to greater } \\
\text { improvement in maximum interincisal opening after } 12 \text { months } \\
\text { than arthrocentesis; however, there was no difference in pain. }\end{array}$ & $1 b$ & $90-91$ \\
\hline & $\begin{array}{l}\text { What is the impact of the information } \\
\text { obtained from magnetic resonance imaging } \\
(\mathrm{MRI}) \text { and computed tomography (CT) } \\
\text { images on the temporomandibular joint } \\
\text { disorder (TMJD) final diagnosis and patient } \\
\text { management? }\end{array}$ & $\begin{array}{l}\text { The absence of studies on the therapeutic efficacy of MRI and CT } \\
\text { on TMJD reinforces the need for investment in decision-making } \\
\text { studies; meanwhile, sectional imaging tests should be prescribed } \\
\text { with caution, especially when health budgets are limited. }\end{array}$ & $\mathrm{N} / \mathrm{a}$ & $99-101$ \\
\hline
\end{tabular}

1. Lawrence A, Richards D. Questions answered in EBD volumes 1 and 2. Evid Based Dent. 2002; 3: 27-29.

2. Richards D. Questions and answers in EBD volumes 3 and 4. Evid Based Dent. 2003; 4: 94-97.

3. Richards D. Questions and answers and guidelines in EBD volume 5. Evid Based Dent. 2004; 5: 110-112.

4. Richards D. Questions and answers and guidelines in EBD volume 6. Evid Based Dent. 2005; 6: 104-107.

5. Richards D. Questions and answers and guidelines in EBD volume 7. Evid Based Dent. 2006; 7: 109-113.

6. Richards D. Questions and answers and guidelines in EBD volume 8. Evid Based Dent. 2007; 8: 118-121.

7. Richards D. Questions and answers and guidelines in EBD volume 9. Evid Based Dent. 2008; 9: 121-125.

8. Richards D. Questions and answers and guidelines in EBD volume 9. Evid Based Dent. 2008; 10: 119-122.

9. Richards D. Questions and answers and guidelines in EBD volume 11. Evid Based Dent 2010; 11: 119-122.

10. Richards D. Not all evidence is created equal — so what is good evidence? Evid Based Dent. 2003; 4: 17-18. 